\title{
Pengembangan Potensi di Bidang Ekonomi, Hukum, dan Pendidikan Pada Masjid Nurul Huda Komplek Taman Kedaung Pamulang Tangerang Selatan. (Sub Bidang :Baitul Mal, Sekolah, dan LBH)
}

\author{
Muhammad Rizal Saragih ${ }^{1}$, Sujarwo, Rusdi ${ }^{2}$, Mawardi Nurullah ${ }^{3}$, Prima Sadewa ${ }^{4}$ \\ a,b,c,dProdi Akuntansi S1, Fakultas Ekonomi, Universitas Pamulang \\ Email : saragihtv@gmail.com
}

\begin{abstract}
Abstrak
Tujuan pengabdian kepada masyarakat ini ialah untuk memberikan pengetahuan, dan pemahaman Baitul Mal, Lembaga Bantuan Hukum, dan peningkatan kualitas Sekolah. Metode pengabdian kepada masyarakat ini ialah seminar, dan diskusi. Populasi dalam kegiatan pengabdian kepada masyarakat ini ialah sebanyak 50 orang yang merupakan pengurus, dan warga Taman Kedaung Tangerang Selatan. Hasil dari pengabdian kepada masyarakat ini ialah seluruh peserta dapat mendirikan Baitul Mal, Lembaga Bantuan Hukum, dan meningkatkan kualitas Sekolah di Masjid Nurul Huda.
\end{abstract}

Kata Kunci : Baitul Mal, Lembaga Bantuan Hukum, Sekolah.

\section{Abstract}

The purpose of this community service is to provide knowledge and understanding of Baitul Mal, Legal Aid Institutions, and improve the quality of schools. This method of community service is seminars and discussions. The population in this community service activity is as many as 50 people who are managers and residents of Taman Kedaung, South Tangerang. The result of this community service is that all participants can establish Baitul Mal, a Legal Aid Institute, and improve the quality of schools at the Nurul Huda Mosque.

Keywords: Baitul Mal, Legal Aid Institute, School.

\section{PENDAHULUAN}

Perkembangan bisnis yang sangat cepat dan dinamis, menuntut para pelaku usaha khususnya pelaku Industri Usaha Mikro Kecil Menengah (IMKM) dan pelaku Usaha Mikro Kecil Menengah (UMKM) harus bergerak cepat mengikuti perkembangan zaman. Tujuannya agar dapat mempertahankan pasar dan konsumen serta memperluas jaringan bisnis. Tuntutan kemajuan teknologi pun dapat menjadi dua sisi mata uang yang berbeda, dapat sangat membantu perkembangan usaha atau justru memperburuk keadaan usaha para pelaku UMKM/ IMKM tersebut. 
Pada dasarnya produk yang dihasilkan dan ditawarkan para pelaku UMKM tidak dapat dianggap remeh, memiliki ciri khas yang berbeda antar satu jenis produk yang sama pun sangat sering terjadi. Untuk itu kelihaian dalam memasarkan produk harus ditingkatkan, akibat tingginya persaingan. Tidak hanya soal pemasaran kesiapan pengelolaan 'rumah tangga' industri juga harus dipersiapkan sebaik mungkin, diantaranya kesiapan pengelolaan bisnis, pengelolaan keuangan usaha, pengelolaan stok barang sampai pada pengelolaan pelayanan konsumen. Untuk mempersiapkan 'rumah tangga' industri demi tetap bertahannya suatu usaha, para pelaku UKM perlu dibantu serta didampingi.

Di Jakarta Selatan khususnya, para pelaku UKM banyak dibantu oleh Rumah Pemberdayaan Masyarakat (RPM). Rumah Pemberdayaan Masyarakat adalah sebuah lembaga nirlaba yang berfokus pada pelatihan dan pendampingan dalam berbagai program-program pemberdayaannya. Selain itu, dalam setiap program Rumah Pemberdayaan Masyarakat menekankan kepada penguasaan bidang Digital. Kenapa harus Digital ? karena saat ini dunia menuju kehidupan yang serba otomatis, manusia mulai tergantikan oleh mesin, software dan peralatan lainnya yang dapat bekerja 24 jam tanpa istirahat sebagaimana manusia yang ada batasnya dalam bekerja. Dengan alasan itu maka penguasaan akan digital marketing sangat ditekankan untuk memenangi persaingan di dunia nyata baik tingkat lokal maupun internasional.

Dari banyaknya jenis usaha perdagangan di Jakarta Selatan, Rumah pemberdayaan masyarakat menggolongkan UMKM berdasarkan lamanya usaha perdagangan dan minimal omset. Untuk jenis usaha perdagangan dengan kategori minimal usaha 2 tahun dan dengan omset minimal lima juta sebulan, digolongkan sebagai kategori UMKM Scale Up. para pelaku UMKM Scale Up harus benar-benar bersaing tidak hanya dari segi pemasaran, tetapi juga kesiapan pengelolaan keuangannya, tujuannya agar para pelaku UMKM Tangerang Selatan dapat melakukan perkembangan usaha dengan tepat dan sesuai sasaran. Lemahnya kesadaran akan pentingnya disiplin pembukuan atau pengelolaan keuangan masih menjadi hal yang serius di lingkungan para pelaku UMKM Tangerang Selatan. Padatnya aktivitas produksi dan pemasaran serta kurangnya informasi mengenai tata kelola 
keuangan yang baik dan sesuai standar yang berlaku (SAK-EMKM), menjadikan pelaku UMKM mengabaikan pencatatan atas transaksi ekonominya. Perlu adanya penyuluhan dan pendampingan mengenai standar keuangan yang berlaku bagi UMKM serta cara termudahnya dalam membantu pengelolaan keuangan baik secara manual maupun digital.

Berdasarkan latar belakang tersebut, kami dari Tim Program Pengabdian Masyarakat (PKM) Universitas Pamulang (UNPAM) yang berjumlah 5 dosen, dan 5 mahasiswa terpanggil untuk ikut serta membantu memecahkan persoalan yang dihadapi oleh masyarakat Pembinaan Kesehjateraan Keluarga. Judul Pengabdian Pengabdian Kepada Masyarakat ini ialah Pengembangan Potensi di Bidang Ekonomi, Hukum, dan Pendidikan Pada Masjid Nurul Huda Komplek Taman Kedaung Pamulang Tangerang Selatan (Sub Bidang :Baitul Mal, Sekolah, dan LBH).

\section{METODE}

Metode kegiatan pengabdian kepada masyarakat ini, antara lain :

\section{Seminar.}

Seminar adalah adalah pertemuan untuk membahas suatu masalah yang dilakukan secara ilmiah. Pada seminar biasanya menampilkan satu atau beberapa pembicaraan dengan makalah atau kertas kerja yang sebelumnya telah di persiapkan. Seminar ini bertemakan perencanaan keuangan, dan penerapan etika bisnis.

\section{Diskusi.}

Diskusi adalah suatu interaksi komunikasi yang terjadi antara dua orang atau secara berkelompok di mana tujuannya untuk membahas suatu tema atau topik tertentu sehingga menghasilkan suatu kesepakatan pendapat. Diskusi dilakukan oleh pemateri dengan peserta sehingga para peserta dapat menerapkan materi yang disampaikan dalam menjalankan bisnisnya.

\section{HASIL DAN PEMBAHASAN}

Populasi dalam pengabdian kepada masyarakat ini ialah sebanyak 50 orang yang merupakan warga sekitar masjid Nurul Huda, Komplek Taman Kedaung Pamulang Tangerang Selatan.

\section{Baitul Mal Merupakan Potensi Yang Harus Dikembangkan Oleh Pengurus}


Masjid Nurul Huda Dalam Bidang

Ekonomi.

Setelah mengikuti kegiatan

pengabdian kepada masyarakat ini, seluruh peserta dapat memahami konsep, tujuan, dan fungsi dari Baitul Mal sehingga pengurus Masjid dapat segera mendirikan Baitul Mal guna meningkatkan tarif hidup warga sekitar.

Sekolah Merupakan Potensi Yang Harus

Dikembangkan Oleh Pengurus Masjid Nurul Huda Dalam Bidang Pendidikan.

Setelah mengikuti kegiatan pengabdian kepada masyarakat ini, seluruh peserta dapat memahami konsep, tujuan, dan fungsi dari Sekolah sehingga pengurus Masjid dapat segera mendirikan Sekolah sesuai dengan jenjang yang diperlukan guna meningkatkan Pendidikan di masyarakat sekitar.

Lembaga Bantuan Hukum (LBH). Merupakan Potensi Yang Harus Dikembangkan Oleh Pengurus Masjid Nurul Huda Dalam Bidang Hukum.

Setelah mengikuti kegiatan pengabdian kepada masyarakat ini, seluruh peserta dapat memahami konsep, tujuan, dan fungsi dari Lembaga Bantuan Hukum (LBH) sehingga pengurus Masjid dapat segera mendirikan LBH guna membantu masyarakat dalam hal menyelesaikan persoalan hukum.

\section{KESIMPULAN}

Kesimpulan dalam pengabdian ini, antara lain :

1. Baitul Mal merupakan potensi di bidang ekonomi yang harus dikembangkan oleh pengurus masjid Nurul Huda guna meningkatkan pertumbuhan, dan perkembangan ekonomi masyarakat sekitar.

2. Sekolah merupakan potensi di bidang pendidikan yang harus dikembangkan oleh pengurus masjid Nurul Huda guna meningkatkan pendidikan, dan pola pikir masyarakat sekitar.

3. Lembaga Bantuan Hukum (LBH) merupakan potensi di bidang hukum yang harus dikembangkan oleh pengurus masjid Nurul Huda guna membantu masyarakat sekitar untuk menyelesaikan persoalan hukum. 


\section{REFERENSI}

Agoes, Sukrisno. (2012). Etika Bisnis dan Profesi. Jakarta: Salemba Empat.

Danim, Sudarwan, (2012.) Inovasi Pendidikan dalam Upaya Peningkatan Profesionalisme Tenaga Kependidikan. Bandung: CV Pustaka Setia.

Exposure Draft Standar Akuntansi Keuangan Entitas Mikro Kecil Menengah (SAK- EMKM). 2016. IAI:Jakarta Selatan.

Ikatan Akuntansi Indonesia atau PSAK (2007:4).

Pedoman Teknis Pencatatan Transaksi Keuangan Usaha Kecil Badan Usaha Bukan Badan Hukum Sektor
Perdagangan. (2015). Bank

Indonesia: Jakarta.

RPIJM (Rencana Program Investasi Jangka Menengah) Bidang Cipta Karya Tahun 2019-2023. 2019. Tangerang Selatan. Bab 2.

Standar Akuntansi Keuangan Entitas Mikro Kecil Menengah (SAK-EMKM). 2018. IAI: Menteng. Jakarta Selatan.

Ritzer, George-Douglas J. Goodman. (2007). Teori Sosiologi Modern. Jakarta : Kencana Predana Media Group.

Slamet J.S. (2009). Kesehatan Lingkungan. Yogyakarta: Gajah Mada University Press.

Soekanto, Soerjono. (2004). Sosiologi Keluarga. Rineka Cipta. Jakarta. 